\title{
Quality of Chief Integrity Officer, Ethical Climate and The Level of Ethics and Integrity in The Malaysian Public Sector
}

\author{
Asmawati Sajari1, Hasnah Haron¹, Ishak Ismail1, and Andrew Chambers ${ }^{2}$ \\ ${ }^{1}$ Faculty of Industrial Management, Universiti Malaysia Pahang, Lebuhraya Tun Razak, 26300 \\ Gambang, Pahang, Malaysia \\ ${ }^{2}$ Cas Business School, London, United Kingdom
}

\section{Abstract}

The purpose of this quantitative study is to examine the relationship between the level of ethics and integrity with Quality of Chief Integrity Officer (independence, competence, work performance) and ethical climate in the Malaysian public-sector organizations. Out of 128 questionnaires that were emailed to $\mathrm{ClOs}$ in the Federal level, 83 questionnaires were received and usable. The results of this study showed that the Quality of $\mathrm{ClO}$ (competence, work performance) and ethical climate is significantly

Corresponding Author:

Asmawati Sajari

watiku049@gmail.com

Received: 5 August 2019

Accepted: 14 August 2019

Published: 18 August 2019

Publishing services provided by

Knowledge E

(c) Asmawati Sajari et al. This

article is distributed under the

terms of the Creative Commons

Attribution License, which

permits unrestricted use and

redistribution provided that the

original author and source are

credited.

Selection and Peer-review under the responsibility of the FGIC2019 Conference Committee.

\section{G OPEN ACCESS}

related to the level of ethics and integrity of the public sector in Malaysia. ClO need to perform their roles such as coordinating and monitoring programs and report any breaches of integrity without fear and favour. To nurture a good ethical climate in the organization, clear policies, guideline and code of conduct should be established in all government ministries, department and statutory body in the public sector. Non-ethical conduct should be reprimanded, good ethical behavior should be rewarded accordingly and should be evident to all in the organization.

Keywords: chief integrity officer, ethical climate, level of ethics and integrity, public sector.

\section{Introduction}

The success of implementing ethics and integrity in the public sector will reduce the ethical scandals such as corruption, bribery, fraud, governance inefficiency, misappropriate of assets, poor internal control, misconduct of behavior and avoiding an adverse effect on government and economy in the future. Thus, ethics and integrity have to be translated into good governance and efficient services delivery by government agencies to prevent issues of integrity in the public sector. In addition, ethics and integrity are two of the key mechanisms of good corporate governance and have become benchmarks for assessing the development of the nation. Without good corporate governance, no reasonable sustainability can be achieved from the part of the country inhabitants and 
the country itself (Ali, 2015). Thus, a case study from Mass Rapid Transit (MRT) committee has been stated that good governance can ensure completion of the massive project ahead of schedule at a lower cost than original estimate budget (Malaymail, 2017).

This is one of the steps to increase towards the level of ethics and integrity in the public sector Malaysia organization. There are several ways to determine the level of ethics and integrity in the public sector. Such as the Public Integrity Index established by Global Integrity is to help control or reduced current corruption, prevent abuse of power, and promote more effective of good governance (Camerer, 2006). Also, there is a comprehensive strategy study to enhance integrity, especially in combating corruption. Among them are studies done by international institutions such as Organizations for Economic Cooperation and Development (OECD). Transparency International (Corruption Perception Index), and Global Integrity (Global Integrity Report). At the national level, there are studies the conducted by Malaysian Institute of Integrity (MII), Malaysian Anti-Corruption Commission (MACC), Public Complaints Bureau and integrity units established in each of the government department, ministry, and statutory body (Siddique. 2010).

The government acknowledged that ethics and integrity in the public sector are important as it is needed to manage and administer an organization and contributes to better deliver services and national development. Thus, Table 1.1 shows the initiatives undertaken by the Malaysian government to enhance ethics and integrity in the Malaysian public sector. Amongst the initiatives include the appointment of the Chief Integrity Officer $(\mathrm{ClO})$ and the implementation of the Certified Integrity Officer (CelO) programme by the Malaysia Anti-Corruption Academy (MACA).

In the public sector, ethical behavior and integrity are important functions in ensuring accountability and transparency. Thus, the Malaysian government had implemented ethics and integrity initiatives even before it gained independence in 1957. In 1950, for example, a commission report on the "Integrity of the Public Services," focusing on corruption offenders was shaped following the enactment of the Corruption Prevention Ordinance 1950 (UKM, 2007). The Corruption Prevention Act 1961 later ensued. Besides, in 1967, the Anti-Corruption Agency was established to eliminate bribery and against the action of unethical in the public sector various departments. Malaysia has been effectively transforming the country from one that is developing into one that will be developed. Before that, the government introduced the strategy known as "Clean, Efficient and Trustworthy" in the 1980s to replace the 1950 Prevention of Corruption Ordinance and the 1961 Prevention of Corruption Agency Act with the aim of ensuring 
TABLE 1: Initiatives taken by Malaysia Government to Promote Ethics and Integrity in the Malaysian Public Sector.

\begin{tabular}{|c|c|}
\hline Year & Milestone \\
\hline 1950 & Prevention of Corruption Ordinance \\
\hline 1961 & Prevention of Corruption Act \\
\hline 1967 & Anti-Corruption Agency (ACA) - Anti-Corruption Act 1967 \\
\hline 1980 & Introduced "Clean, Efficient, Trustworthy" \\
\hline 2004 & $\begin{array}{l}\text { Establishment of the Malaysian Institute of Integrity (MII) Launching of the National } \\
\text { Integrity Plan (NIP) }\end{array}$ \\
\hline 2006 & Establishment of the Malaysia Anti-Corruption Academy ((MACA) \\
\hline 2008 & $\begin{array}{l}\text { Establishment of the Corporate Integrity Development Center (CIDC) * Putting the } \\
\text { Chief Integrity Officer (CIO) from ACA "Kader" at ministries, departments, agencies } \\
\text { in high risk unethical scandal. }\end{array}$ \\
\hline 2009 & $\begin{array}{l}\text { Transformed: Anti-Corruption Agency (ACA) to Malaysia Anti-Corruption } \\
\text { Commission (MACC's) - MACC Act } 2009 \text { Implementation of the Certified Integrity } \\
\text { Officer (CelO) Programme Establishment of Committee on Integrity (CIG) }\end{array}$ \\
\hline 2013 & Established of the Agency Integrity Management Division (AIMD) \\
\hline 2014 & $\begin{array}{l}\text { Establishment of Integrity and Governance Committee - Chief Integrity Officer (CIO) } \\
\text { have a certificate of integrity officer as its Head Integrity Unit }\end{array}$ \\
\hline $2019-2023$ & National Anti-Corruption Plan (NACP) \\
\hline
\end{tabular}

the prevention of corruption and increasing the practise of integrity in the public sector various departments (Lokman. A \& Talib T. A, 2015).

In the public sector, the government also established several control mechanisms to introduce accountability in spending to organizations. In 2004, the Malaysian Institute of Integrity (MII) was established as an initiative by the government to create a nation with a high level of integrity which would be resilient and embody the universal good value. In the same year, the National Integrity Plan (NIP) was introduced as a major effort made by the government to promote a culture of integrity. MII provides a framework that would support the effective coordination and implementation of NIP. Chaired by the Chief Secretary to the government and governed by a Board of Directors, MII is responsible for monitoring and coordinating and implementation particularly devising appropriate indices to measure performance in achieving NIP targets, preparing annual reports to Malaysia Integrity system and organizing conventions of stakeholders to debate integrity issues seeking new and innovative ways to move forward (Siddique, 2010). 
In 2006, the Malaysian government established the Malaysia Anti-Corruption Academy (MACA) to provide trainers and experts to formulate and conduct, training, seminar, and workshop in fighting corruption. In 2008, the government established the Corporate Integrity Development Centre (CIDC) that is responsible for developing course modules for the Certified Integrity Officer program. The course modules were developed with the cooperation of government agencies and government-linked company (GLCs). In August 2008, MACC placed their Chief Integrity Officers as "kader" at ministries, department and agencies governments that have a high risk of corruption. There are three levels of risk in the public sector, and they are at high risk, medium risk, and low risk. The federal government was said to have a moderate to high risk, and the state government was said to have a low risk in Circular No.6 (2003).

On $1^{\text {st }}$ January 2009, ACA was transformed to become the Malaysian Anti-Corruption Commission (MACC) whose main function was to enforce the law to prevent corruption. There are three pillars of integrity which are (i) education and awareness (ii) prevention and government, and (iii) detection and consequence management (Norazlan M.R, 2013). In 2009, the Committee on Integrity Governance (CIG) was established. The purpose of $\mathrm{ClG}$ is to improve the administration of the government, enhance governance, reduce bureaucratic, and prevent corruption. The Certified Integrity officer programme requires a $\mathrm{ClO}$ to undergo a six-months training by MACA This programme expectations to be able to curb unethical issues at various levels of the organizations. The objectives of the programme are (i) promote compliance in terms of laws and regulations, system and procedure, (ii) foster zero tolerance towards fraud, corruption, and abuse of power, and (iii) consult and advise the organisation's management on awareness and preventive measure (NKRA E-Newsletter, 2013). This is one of the efforts initiated by the government to increase ethics and integrity in the public sector. Upon the recommendation by MACC in 2013 , Unit Integrity was established to further enhance integrity in all federal and state government agencies. This will prevent criminal misconduct and violations of the code of conduct and ethics in the civil services organization. As a Head of the Integrity Unit who has a certificate as an integrity officer, the $\mathrm{ClO}$ will manage and implement active initiatives in integrity, managing complaints, prevention, compliance, detection disciplinary actions in governments agencies

Currently, in 2019, the Malaysian government has promoted a new initiative to combat corruption which is the National Anti-Corruption Plan (NACP) and will be launched by the Prime Minister of Malaysia, Dato'. Seri Dr. Mahathir Mohammed. The National AntiCorruption Plan (NACP) is an anti-corruption policy in Malaysia that reflects the people's 
expectations for a greater corrupt-free nation that promotes transparency, accountability and integrity culture in every Malaysians and will be replacing the National Integrity Plan. With the establishment of NACP, it is hoped that the ranking of corruption will decrease, and Malaysia will become an inspiration for other countries thus become a benchmark to combat corruption in the public sector (GIACC, 2019).

\subsection{Problem Statement}

This study will determine the level of ethics and integrity in the public sector. Quality of $\mathrm{ClO}$ and ethical climate are hypothesized to be a factor that will influence on the level of ethics and integrity. Based on the Transparency International (TI) Corruption Perception Index (CPI), there are cases of allegations of corruption in the newspapers and social media that highlighted unethical behavior and integrity as the main problem in the public sector. Even though the Malaysian government has implemented various initiatives to reduce the occurrence of unethical scandals in the public sector, but statistics reports still show an increase every year (Siddiquee, 2010). Previous studies show that having a corporate integrity system in an organization, will lead to a good level of ethics and integrity in the workplaces. However, the research has been conducted in listed companies. Meanwhile, the study of this research would assist the government in identifying the factors that would assist in nurturing and promoting the value of integrity in the government sector.

According to the Asia Pacific Fraud Survey Report Series 2013, it has been noted that the highest level of bribery and corruption is from Malaysia and China. A survey by Transparency International - Malaysia (TI-M) on Corruption Perceptions Index in the public sector, also shows the "scores" and "ranking" dropped in 2016, 2017 and 2018. Example due to drop such as 1 Malaysia Development Berhad (1MDB), SRC International Sdn. Bhd case, and Federal Land Development Authority (Felda) scandal (Theedgemarkets, 2018). This is indicating that graft-fighting measures efforts are still inadequate to fighting corruption, even though the government is on the right way to restore public confidence. Numerous steps should be taken to improve public awareness, mainly towards public sector accountability (Said, Alam, \& Khalid, 2015). However, the issue of corruption and unethical conduct remains critical. Table 2 shows the annual statistics on arrests up to July 2016, which comprised of 588 cases whereby 296 cases involved public sector officials. 
TABLE 2: Annual Statistics on Arrest as of July 2016 ( $n=588)$.

\begin{tabular}{l|c|c|c|c|c|c|c|c|}
\hline Month & Jan & Feb & Mac & Apr & May & Jun & Jul & Total \\
\hline Top Management & 0 & 0 & 1 & 0 & 0 & 0 & 0 & $\begin{array}{c}\text { Public } \\
\text { Official }\end{array}$ \\
\hline $\begin{array}{l}\text { Professional and } \\
\text { Management }\end{array}$ & 15 & 6 & 7 & 7 & 5 & 23 & 5 \\
\hline Support Staff & 38 & 39 & 31 & 25 & 42 & 33 & 19 & 296 \\
\hline Total & 53 & 45 & 39 & 32 & 47 & 56 & 24 & Civilian \\
\hline Private Sector & 30 & 8 & 44 & 28 & 14 & 9 & 6 & 13 \\
\hline General Public & 23 & 14 & 21 & 30 & 36 & 14 & 0 \\
\hline Local Councillor & 0 & 0 & 0 & 0 & 0 & 0 & 0 \\
\hline Politician & 0 & 0 & 1 & 0 & 0 & 1 & 0 \\
\hline Total & 53 & 22 & 66 & 58 & 50 & 24 & 19 \\
\hline
\end{tabular}

Table 3 shows the percentages of fraud cases based on the different number of government agencies. Research conducted by Kamaliah, Marjuni, Mohamed, MohdSanusi \& Anugerah (2018), shows that the higher percentages are fraud cases namely, misappropriate of assets, followed by theft, procurement fraud, bribes, payroll fraud and, financial statement fraud in the federal government agencies. Meanwhile, a percentage of fraud cases misappropriation of assets in local government agencies is the lowest percentage compared to the federal government agencies. Therefore, having a Chief Integrity Officer and a good ethical climate at the workplace will help to enhance ethical practices among employees and as a result, will reduce misconduct in the public sector organisation.

TABLE 3: Percentage of Fraud Cases Based on The Type of Government Agencies.

\begin{tabular}{l|c|c|c|}
\hline Fraud & Federal (\%) & Local (\%) & Others (\%) \\
\hline Bribery/kickbacks & 24.18 & 10.99 & 12.09 \\
\hline Theft & 36.26 & 14.29 & 17.58 \\
\hline Misappropriate of assets & 37.36 & 16.48 & 17.58 \\
\hline Procurement Fraud & 35.16 & 14.29 & 15.38 \\
\hline Payroll Fraud & 14.29 & 4.40 & 9.79 \\
\hline Financial statement fraud & 7.69 & 0.00 & 2.20 \\
\hline Source: Kamaliah, Marjuni, Mohamed, Mohd-Sanusi \& Anugerah (2018)
\end{tabular}


A research conducted by Accounting Research Institute (ARI, 2016) found that the government-related parties request for bribe more than the others, as shown in Figure 1. In this study, questionnaires were distributed to both technical and non-technical employees in both the public and the private sector. The questionnaire asks the respondents to rate which party requests for consultbribe the most when dealing with business transactions with them. Findings show that the most party that requests for a bribe is the government official (38\%).

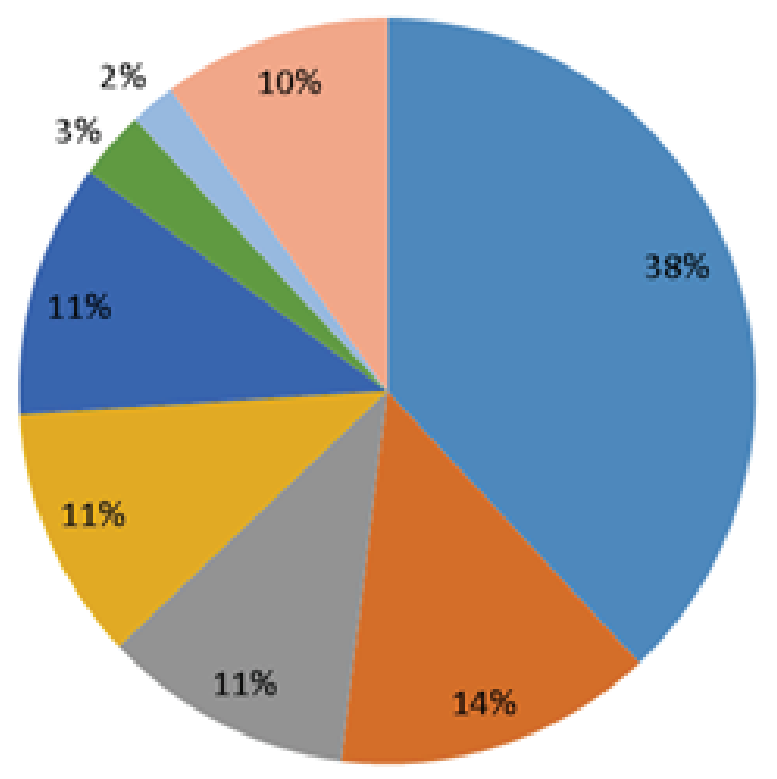

= Government Official

= Government Employee

$=$ Police

= Member of Judiciary

= Ruling Party Official

= Private Company

Representative

= NGO Representative

m Other

Figure 1: Who Requested the Bribe? (Source: Accounting Research Institute (2016))

Thus, Prime Minister Directive No. 1 of 2009 has taken a vital step to encourage further on integrity. This directive is a mandate establishment of a committee on integrity governance in all government ministry and departments. The Certified Integrity Officer (CelO) is an accredited officer that plays an integral role within an organization to inculcate integrity and ethical values. A prepared CelO would have a decent comprehension of Integrity Management, the required Legal Framework and Compliance, and Monitoring System just as the capacity to build up an Integrity Action Plan. One of the mechanisms to push companies to follow ethical conduct is through the appointment of an ethical and compliance officer. Similar terms used for ethical and compliance officer includes Compliance Officer (CO), Ethics and Compliance Officer (ECO), Chief Ethics and Compliance Officer (CECO) and Chief Integrity Officer (CIO). This officer is expected to guide and protect an organisation from unethical behaviour that will harm the organisation's reputation. They are also expected to formulate and review corporate integrity strategy and action plan to promote integrity and set up personnel and integrity committee at the 
board level. This position is one of the most important positions in the company because he/she is responsible for creating and maintaining organization environments that aim to produce ethical and law-abiding employees and leaders (Treviño, den Nieuwenboer, Kreiner, \& Bishop, 2014). Furthermore, the Malaysian Anti-Corruption Academy (MACA), through its Corporate Integrity Development Centre (CIDC) conducted a CelO program for this purpose. All CelOs will be awarded a certificate by MACA. This CelO program has been implemented for more than five (5) years. In Malaysia, a ClO is a Senior Officer from MACC that acts as an advisor in their agency. This position was created to ensure that there is an improvement in the level of ethics and integrity in the public sector, as corruption and bribery are getting more severe by the day. Malaysia views this issue unethical and lack of integrity in the public sector seriously. Therefore, government has emphasised that the public sector in Malaysia needs to be effective, efficient, and ingrained with the highest level of ethics and integrity. This is so that Malaysia will be able to move towards achieving a high-income economy status in 2020 . Thus, the importance of a good quality $\mathrm{ClO}$ and ethical climate in the organizations will help to ensure the achievement of this objective.

In this study, $\mathrm{ClO}$ is perceived as a person who has an important role and responsibility to ensure that ethics and integrity is implemented in the organization. However, there is no latest research conducted with the knowledge of the researcher, to evaluate the effect of $\mathrm{ClO}$ on the level of ethics and integrity in Malaysia's public sector. Therefore, one of the objectives of this research is to examine this issue. The research will examine the relationship of $\mathrm{ClO}$ s on the level of ethics and integrity in Malaysia's public-sector organizations. If ClO's relationship is positive on the level of ethics and integrity in an organisation, then this programme would be recommended to be continued otherwise, an intervention or improvement is needed to relook at other alternatives to improve the level of ethics and integrity of an organisation. Previous research has shown that having a quality $\mathrm{ClO}$ (Chandler, 2015; Treviño et al., 2014) and a good ethical climate (Kolthoff, Erakovich \& Lasthuizen, 2010) will enhance the level of ethics and integrity in an organisation. Therefore, this study will examine the issue in the Malaysian context. The findings of this study may help the public sector to increase the level of ethics and integrity in their organisations and assist in preventing unethical conducts. If the problem of ethics and integrity is resolved, it will encourage investors from abroad to come and invest in this country. This will help to increase economic growth and develop Malaysia to achieve a high-income economy status in 2020. 


\subsection{Research Objectives}

The objectives of this study are as follows:

1. To examine the relationship between Quality of Chief Integrity Officer (CIO) i.e independence, competence, and work performance with the level of ethics and integrity in the Malaysian public sector.

2. To examine the relationship between ethical climate with the level of ethics and integrity in the Malaysian public sector.

\section{Literature Review}

Previously, the Malaysian public sector is known as the Malaysian Civil Service (MSC). It is divided into three tiers governments, namely, i) federal government ii) state government iii) local government (Azleen \& Nurul, 2013). The Federal Government is the Central Government with 25 Federal Ministries headed by Ministers, administrative heads and the Secretaries-General. Meanwhile, 13 of State Governments implementing state functions with Federal Department. Also, generates own revenues and incur their own expenditures even though the Federal Government undertakes projects at the state level agreed upon in the Concurrent List and Federal List in the Constitution of Malaysia. There are federal statutory bodies and state statutory bodies. The complexity of structure requires the Malaysian government to adopt a comprehensive procedure and guidelines especially related to planning and control on the financial management matters (Ali, 2015). Malaysia is no exception towards promoting integrity and curb of corruption has become a significant component of government reforms such as many countries. Economic Transformation Program (ETP) is a system of Malaysia government to become a high-income nation by the year 2020. The Anti-Corruption Agency was established in 1967 with clear mandates, it was reformed and revitalized subsequently to make it more effective in containing corruption and all forms of maladministration in the society. Since the year 2003, fighting corruption has been steadfast in the government agenda. The variety of new initiatives and strategies have been planned and implemented ever since. In addition, Malaysia also has an elaborate anti-corruption framework. However, Malaysia presents an interesting case where the level of corruption has remained high and the plethora of strategies and recent campaigns appear to have made hardly any difference in containing and combating corruption in the society (Siddiquee, 2010). 


\subsection{Theory}

This study applies the Hunt and Vitell Theory of Ethics (1986). This theory examines of ethical dilemma and ethical decision-making on individual arrive at the level of ethics and integrity in the organizations. Hunt and Vitell Theory, explain that behavioural consequences impact future deliberations regarding ethical issues, presupposing that the decision-maker reaches a "right" or a "wrong" decision that informs subsequent ethical decision making (Pimental et al., 2010). Thus, personal characteristics (e.g., attitudes, and knowledge) will explain the relationship between of Quality of $\mathrm{ClO}$ (Independence, competence, work performance) with the level of ethics and integrity. Meanwhile, organizational environment will explain the relationship between ethical climate with the level of ethics and integrity.

\subsection{Quality of Chief Integrity Officer $(\mathrm{ClO})$}

Despite growing research in behavioral ethics, little is known about one of the most important ethics-related roles in organizations. There are numerous names given for the ethics-related role such as Ethics and Compliance Officer (ECO) (Chandler, 2015; Treviño et al., 2014), Compliance Officer (CO) (David Chandler, 2015), Ethics Ambassador (Irwin \& Bradshaw, 2011), Ethics Officer and Chief Ethics Officer (Guten et al., 2004). In Malaysia, Chief Integrity Officer (CIO) was introduced (Circular No. 6, 2013). Prior to that, MACA had conducted specialized training programme of Certified Integrity Officer (CeIO) to prepare these CIUs for their role and responsibility. In this study, the quality of $\mathrm{ClO}$ (Chief Integrity Officer) will use the measurement of independence, competence and work performance as a factor that influence the level of ethics and integrity in public sector organization.

\subsubsection{Independence}

Independence is the freedom from a condition that threatens the objectivity or the presence of objectivity (IIAM, 2008). According to Qun (2013), independence for internal audit is an important characteristic that must be involved to confirm that internal audit is adequately effective. His study measures the independence based on reports for administrative report purposes, in most situations, the CAE should report straight to the chief executive officer of the organization. Administrative reporting is the reporting 
related in the organization's management structure that facilitates the daily procedures of the internal audit such as, human resources administration, including, budgeting, administration of the organization's policies and procedure. In the case of $\mathrm{ClO}$, reporting operationally refers to reporting within the organization's management structure that facilitates the day-to-day operations of the internal activity, for example, to coordinate and monitor integrity programs of the $\mathrm{ClO}$ that requires reporting to Head of Department.

\subsubsection{Competence}

According to Thomson (1995), competence is defined as "attributes needed by an individual to perform work. An individual becomes competent through a combination of education, training and work practices. Competence has been classified to have four facets which are professional, methodological, social and self-competence (Kauffeld, 2006). Measuring professional competence addresses the skills, knowledge and all employees have to have in order to practice his or her occupation. It is also to identify potential for improvement within the company and develop a relevant technical solution (Kauffeld, 2006, Heinen, 2013). Competence methodologies are the cognitive skill of an individual to learn new working methods independently or gain new expertise (Erpenbeck and Michel, 2006). These skills should be used across any setting and applied to any particular situations (Heinen, 2011: Kauffeld, 2006). Social competence involves the experience, knowledge and ability to cope with various social interaction situations (Frey and Ruppert, 2013; Kauffeld, 2006). Self-competence is the ability for self-assessment and for the independent creations of conditions in which an individual, as well as their value and attitude towards their own work, are developed (Frey and Ruppert, 2013, Kauffeld, 2006). Competence is one of the important characteristics of an employee and employer in an organization. It is important because this criterion will show in their work outcome whether it be good or bad in all tasks done. Individual competence can be described as a set of skills and knowledge that an individual need in order to perform a specified job effectively (Baker et al., 1997).

According to Qun (2013), the definition of competence is the quality of being adequately or well qualified physically and intellectually. Meanwhile, the measurement of competence also looks at years of experience and educational qualification level. $\mathrm{He}$ conducted the study on the competence of internal auditors based on the sum of mean educational qualification level among audit staff, which an internal auditors' average score of four will be awarded for "PhD," three for "master," two for "degree" and one 
for "diploma". The mean of educational qualification is the sum of the score divided by the maximum score given to the number of staffs. For experience work, based on the average of the year, the more experienced staff usually have accumulated extra knowledge and skills, therefore the score of six will be awarded for "more than 15 years", five for " 12 to less than 15 years", four for " 9 to less than 12 years", three for " 6 to less than 9 years", two for " 3 to less than 6 years" and one for "Less than 3 years". The mean of experience is derived by dividing the sum of the score by the maximum score. Similarly, in this study, the measurement of $\mathrm{ClO}$ competence will be based on the educational qualification level and working experience.

\subsubsection{Work performance}

The definition of work performance is the behaviors or actions that contribute to the goals of the organization (Campbell's, 1990). There are three views of on different definitions of work performance namely: (i) in terms of behavior rather than results, (ii) includes only those behaviors that are relevant to the organization's goals and (iii is multidimensional. Meanwhile, Viswesvaran and Ones (2000) defined work performance as accessible activities, behavior, and results that employees engage in or bring about, that are related to and contribute to organizational goals. Besides that, the definition of work performance (IIAM, 2008) is a process of procedures that includes audit planning, performing engagement and communicating audit results. According to studies done by Qun(2013), work performance is the responsibility of the internal audit to ensure the achievement of objective effects and quality of work performance. This ensures that entirely planned work is a priority and that audit resources are applied in a good possible method. The IIA Performance Standard 2200 (IIAM, 2008) deals with engagement planning and states that internal auditors should develop and record a plan for each engagement, including the scope, objective, timing and resource allocations. Engagement planning involved the adequacy of the scope of work and related programs whether it is, performed by people having adequate technical training and expertise. His studies were used as a measurement of work performance in engagement planning, an accomplishment the engagement and communicating results of the engagement. In this study, work performance is defined as the role that the $\mathrm{ClO}$ must ensure the level of ethics and integrity of an organization. The roles are as listed in Circular Series 1 No.1 (2011) which are the ClOs' roles. 


\subsection{Ethical Climate}

The stories of collapse companies such as Enron, Tyco, and World Com proven that ethics and integrity are the most of important elements in governance that affect not only organizational effectiveness but also survival skills. (Bartels et al., 1998; Buller and McEvoy, 1999; Hunt et al., 1989). The ethical climate is important in the organization because one of the factors influencing the employees' perception in emphasize the ethical guideline of organizations and encourage employees' ethical work behaviour at the workplace. (Martin and Cullen, 2006; Schminke et al., 2007) as cited in the study done by Kwon Choi et al., (2013). Based on previous research, Victor and Cullen (1988) defined ethical climate as "the prevailing perceptions of distinctive organizational follows and procedures that have ethical content" or "those aspects of work climate that determine what creates ethical behaviour at work. Ethical climate can be measure with four-item subscales which follows nine theoretical dimensions of ethical climate and they are self-interest, company profit, efficiency, friendship, team-interest, social responsibility, personal morality, rules, and standard operating procedures and laws and professional codes. The ethical climate is the perception of what constitutes the right behaviour. Ethical climate influences both decision-making and subsequent behaviour in response to ethical dilemmas (Martin and Cullen, 2006). The concept of ethical climate is powerful and according to Sims (1992) as cited in Laratta (2008) whereby the ethical climate of an organization is the shared set of identifications about what correct behaviour is and how ethical issues will be handled. This climate sets the tone for decision making at all levels and in all circumstances. In their paper, Abdullah, Sulong, and Said (2014) used the term ethical climate interchangeably with the ethical culture. Ethical climate/culture measurement is implemented from the scale developed by Victor \& Cullen (1988) and Suar \& Khuntia (2004). This is based on ten-item that measures management perception on ethical climate in the present organization. This research used the ethical climate questionnaire (ECQ) developed by Victor and Cullen (1998).

\subsection{Level of Ethics and Integrity}

Corporate Integrity Assessment Questionnaire (CIAQ) is a tool introduced and made available by the Malaysian Institute of Integrity (IIM) to measure the level of corporate integrity in late 2010. Thus, organizations will be using CIAQ as a tool to assess the 
improvement in making a transparent assurance to ethics and integrity in the workplace. As shown in Table 4, studies by Rosli et al., 2015) have used these twelve dimensions of corporate integrity system. According to Said and Omar (2014) using the Corporate Integrity System questionnaire (CIAQ) studies on two giant government-linked companies shows that finding found that the level of ethics and integrity on the average is $50 \%$. Company A's level of ethics and integrity is $67.7 \%$ (Utility Company) which is higher than Company B's level of ethics and integrity of 59.7\% (Healthcare Company). Company A scored higher than Company B in terms of Vision and Goals, Legal Compliance, Policies and Rules, and Corporate Social Responsibility. The score for Corporate Social Responsibility is highest for both companies, however, for infrastructure both companies had the lowest score. Infrastructure is the way that organization structures, organizes its ethics and integrity function so that it can convey out its goals effectively. The lowest score shows that these two leading GLCs placed less emphasis on integrity infrastructure to support the companies to convey out its integrity's goals effectively (Said \& Omar, 2014).

\subsection{Relationship between Quality of $\mathrm{ClO}$ (Independence, Com- petence, Work Performance) and Ethical Climate to Level of Ethics and Integrity}

\subsubsection{Quality of $\mathrm{CIO}$}

To further examine this area, this study examines the existence of quality of Chief Integrity Officer $(\mathrm{ClO})$ that might influence the level of ethics and integrity in the public sector Malaysia. Meanwhile, based on Hunt and Vitell's Theory of Ethics (1986), itis more positive rather than normative approach (Torres, 2001). In other research by Zakaria, Haron, and Ismail (2010), they cited that Hunt and Vitell's (1986) theory of ethics states that personal characteristic influences perceived ethical problems, which in turn influences the formation of ethical judgement. Therefore, using this theory best solves the problem and to find out the level of ethics and integrity in public sector organizations. Malaysians need to attain the most beneficial outcome. As cited in Chandler (2015), the existence of the Ethics and Compliance Officer (ECO) position represents the enactment of values in relation to ethical behaviour (Weaver et al., 1999a). This means that through resource commitments, what is the implementation and the response of stakeholders to these commitments. This is important because, in order to remain relevant, institutions must be actively maintained (Dacin, Munir, \& Tracey, 2010; Lok \& de Rond, 2013). It is 
believed that the contacts that the employees have with their ECO via helpline are a direct reflection of the ECO's ability to generate an "ethical culture," which is connected to the ethical behaviour of its employees. Therefore, based on the previous studies the hypotheses as follows:

$\mathrm{H}_{1}$ : There is a significant relationship between the Quality of chief integrity officer with the level of ethics and integrity.

Independence of this studies is supporting the view of audit committee contributes positively to ethical reporting relation between audit committee independence, which unethical reporting without interference from other parties. Blue Ribbon Committee (1999) state that audit committee independence is positively related to the number of its outside directors who have no personal or financial relations with the firm or its executives. Chandler (2015) cited that ECO implementation captures both the scale and scope of organizational resource commitments to the ECO position. Access to both tangible and intangible resources is understood by management researchers to be a source of power and legitimacy within the firm (Cyert \& March 1963). Besides that, Abbott et al. (2004) and Persons (2005) find a negative association between the audit committee independence and the probability of financial reporting restatement and financial reporting fraud. Therefore, based on the previous studies the hypotheses as follows:

$\mathrm{H}_{1 a}$ : There is a significant relationship between the independence of the chief integrity officer with the level of ethics and integrity.

Nabila (2008) found that competence has a significant relationship with organizational commitment. Zahariah, et al., (2009), Sethela and Rosli (2011), Mujeeb, et al (2011), Selma (2011), Simpson (2012), which indicated that there is a direct and indirect relationship between competence (ability), motivation and organizational culture on organizational commitment. Ulrich (1998), stated that the success of organizations will not be achieved if commitment without competence is not implemented to maintain a sustainable in the organization. Hsiang Wu (2010), the analysis result that competency training was positively related to organizational commitment. Competence plays a significant relationship with ethic and integrity in a few significant ethical judgment models by Hunt \& Vitell Theory of Ethics, (1986). According to Hunt \& Vitell, competence influence ethicalness on organizations. Therefore, based on the previous studies the hypotheses as follows:

$\mathrm{H}_{1 b}$ : There is a significant relationship between the competence of the chief integrity officer with the level of ethics and integrity. 
Studies (Koopmans et al., 2011) found that work performance is a behavior or action that is relevant to the organization. Whereby, the dimension of work performance that comprises namely task performance which are work quantity and quality, job skills and knowledge and context performance which are showing responsibility, communicating effectively, job-scope and cooperating with others. These two elements have a relationship with the outcome of good performance towards the goal of the organization. Meanwhile, Qun (2013) stated that a relationship on work performance might affect the internal audit and its efficiency. The significant relationship shows that the quality of work performance which are planned, performed, reviewed and suitability of audit is vital to ensure the objective is accomplished and engaged effectively and efficiently in the organization. Therefore, based on the previous studies the hypotheses as follows:

$\mathrm{H}_{1 b}$ : There is a significant relationship between the competence of the chief integrity officer with the level of ethics and integrity.

\subsubsection{Ethical Climate}

Meanwhile, organizational ethical climate refers to a few models of ethical judgment support that has a significant relationship with a perceived ethical problem. Hunt and Vitell's Theory of Ethics (1986) also posits that the organizational environment influences people in perceiving ethical problems. Similarly, prior studies indicate that the more ethical the employees perceived the climate in their organization, the higher their ability to perceive ethical problems (Marta, 1999; Patterson 1994). Hence, the less likely an unethical judgment can occur. In addition, Shafer (2015) studies the ethical climate of professional accountants in Hong Kong and results show that an ethical climate has a significant relationship with ethical judgements in the organizations. This result is in line with his previous which examines local and international CPA firms in China (Shafer, 2008). It looks that there is a significant relationship between perceived ethical climate and the intention to conduct questionable actions (Haron, Ismail, \& Na, 2015). Haron et al. (2015) found that the level of perceived ethical climate has a positive effect on the ethical conclusions made. This result is also consistent with the findings of Ghazali and Ismail (2013) whereby the accountants who are attached to corporations with higher ethical standards are stricter in making results in questionable ethical conduct. Therefore, based on the previous studies the hypotheses as follows:

$\mathrm{H}_{2}$ : There is a significant relationship between ethical climate with the level of ethics and integrity. 
All the above relationships mentioned above can be related to the level of ethics and integrity in the organization. In other words, the quality of $\mathrm{ClO}$ namely independence, competence, work performance and ethical climate of the organization influences the ethical decision making and eventually gives an impact on the level of ethics and integrity.

\subsection{Theoretical Framework}

Figure 2 shows the Theoretical Framework; this study utilizes the principle of Hunt and Vitell's Theory of Ethics (1986). As stated in the theory, personal characteristics and environment of organization influence the perceived the level of ethics and integrity. Following this theory, this study posits that Quality of $\mathrm{CIO}$ and ethical climate has a significant relationship with the level of ethics and integrity in the organizations.

Independents Variable

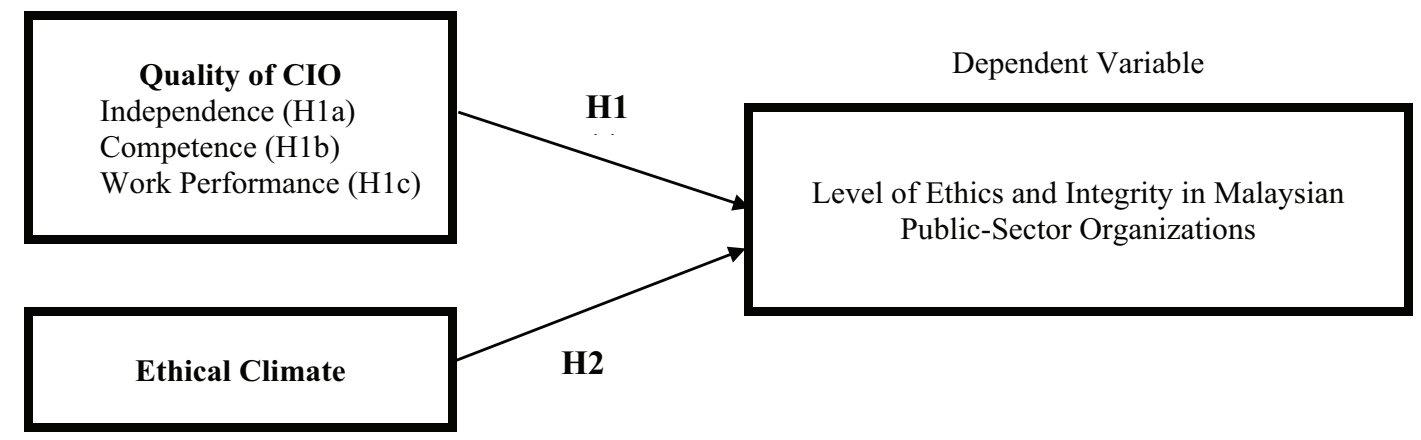

Figure 2: Theoretical Framework.

\section{Methodology}

\subsection{Research Design}

The research design of this study is exploratory research. Exploratory research helps to determine the best research design, data collection methods, and selection of subjects. This research was also analysed with the help of statistical tools to find the answer for the research questions. 


\subsection{Population and sampling technique}

The population of this research is 128 officers in charge of ethics and integrity in their organisation. It is confined to the Federal Government as it has moderate to a high level of risk as compared to the State Government which has a low risk. The names of $\mathrm{ClO}$ s have been provided to the researcher by the Corporate Integrity Development Centre (CIDC) and all 128 officers have completed in taking the training modules offered by CIDC of MACC as of August 2017. The total of 128 officers includes ClOs, compliance officer, assistant director, investigation officer, secretariat department, director of integrity unit, senior compliance, governance and integrity centre. By using 4 variables and the Sekaran's rule of thumb. To calculate the sample size, 4 variables and the Sekaran's rule of thumb were used. Sample size of 40 to 50 officers would be enough for this study. This study used the sampling method that selected 128 officers of $\mathrm{CIO}$ who have been attending the CelO programme at federal territory were included.

\subsection{Measurement of variable}

\subsubsection{Quality of $\mathrm{ClO}$ will use measurement of independents, compe- tence and work performance as factor influences the level of ethics and integrity in public sector organization.}

Independence is based on the level of functional reporting and administrative reporting (Qun, 2013). Whereby ClO should report functionally to the General Secretary of Ministry with a score of " 5 ", score "4" for Ministry, score "3" for Chief Executive Officer, score "2" to Head of Department and score "1" to other bodies in the organization. However, independence of $\mathrm{ClO}$ in administrative reporting which is the daily reporting to the Head of Department is important and should be done.

Competence of Chief Integrity Officer is measured based on the sum of mean educational qualification level with experience. Whereby, an educational score of " 4 " was for Ph.D., "3" for master, "2" for degree and "1" for the diploma. For experience on average, the further experienced staff usually have accumulated more knowledge and skills, whereby the score was " 6 " for more than 15 years, " 5 " for " 12 to less than 15 years", four for " 9 to less than 12 years", three for " 6 to less than 9 years", two for " 3 to less than 6 years" and one for "Less than 3 years". The mean of experience is derived by dividing the sum of the score by the maximum score (Qun, 2013). 
Work performance, $\mathrm{ClO}$ must identify, analyse, evaluate, and record sufficient information to achieve the engagement's objectives. Also, had better identify sufficient, consistent, relevant, and useful information to use in analysing and evaluating the engagement before drawing conclusion and engagement in making a decision (Qun, 2013, IIAM 2008). Thus, the measurement work performance of $\mathrm{ClO}$ is self-developed based on the roles Certified Integrity Officer in Circular No. 12009 and Series 1, No. 1 2011. The $\mathrm{ClO}$ has ten roles, and they are. 1) Coordinate and monitor integrity program, 2) Report any breach integrity, 3) Coordinate the actions taken on breach of integrity, 4) Implement the recovery program on integrity 5) Publication of integrity-related article, 6) Assist and support of Committee on Integrity, 7) Advice management on integrity matters, 8) Monitor the system services delivery system, 9) Act as a liaison Officer organization to corporate and 10) Ensuring compliance to directive/regulations issued by organization. The respondent is required to rate the level of agreement from scale 1 (strongly disagree) to scale 5 (strongly agree), which shows the measurement items for the work performance of $\mathrm{ClO}$.

\subsubsection{Ethical Climate}

Measurement of Ethical climate of this study based on the Ethical Climate Questionnaire (ECQ) developed by Victor and Cullen $(1987,1988)$ and further confirmed by Cullen and Bronson (1993). There are nine dimensions to measure the ethical climate, and they are employee-focused climate, community-focused climate, obedience to authority, code implementation, self-interest climate, efficiency climate rules and procedures climate, personal ethics climate and law, and professional climates. Respondents are required to indicate the degree of agreement using a 5-point Likert scale ranging from 1 (strongly disagree) to 5 (strongly agree). In this study, the ethical climate is treated as unidimensional regardless of the dimension based on the concept through ( Jaramillo et al., 2006; Schwepker, 2001).

\subsubsection{Level of Ethics and Integrity}

Dependent variables of this study are the level of ethics and integrity. This variable is measured by 12 dimensions (See Appendix 1) of CISM developed by Institute of Integrity Malaysia with a total of 208 items statements. It is adapted from Dubinsky and Richter (2008-2009). Global Ethics and Integrity Benchmarks as Figure 3. These benchmarks 
reflect emerging successful organizational practices. The respondents are required to rate the statements on a five-Likert scale with "0" Not Sure; "1" Strongly Disagree; "2" Disagree; "3" Agree and "4" Strongly Agree. Mean and frequency will be used in explaining the data during the analysis. Meanwhile, Descriptive of CISM 12 Categories Items for Level of Ethics and Integrity: Refer Appendix 1

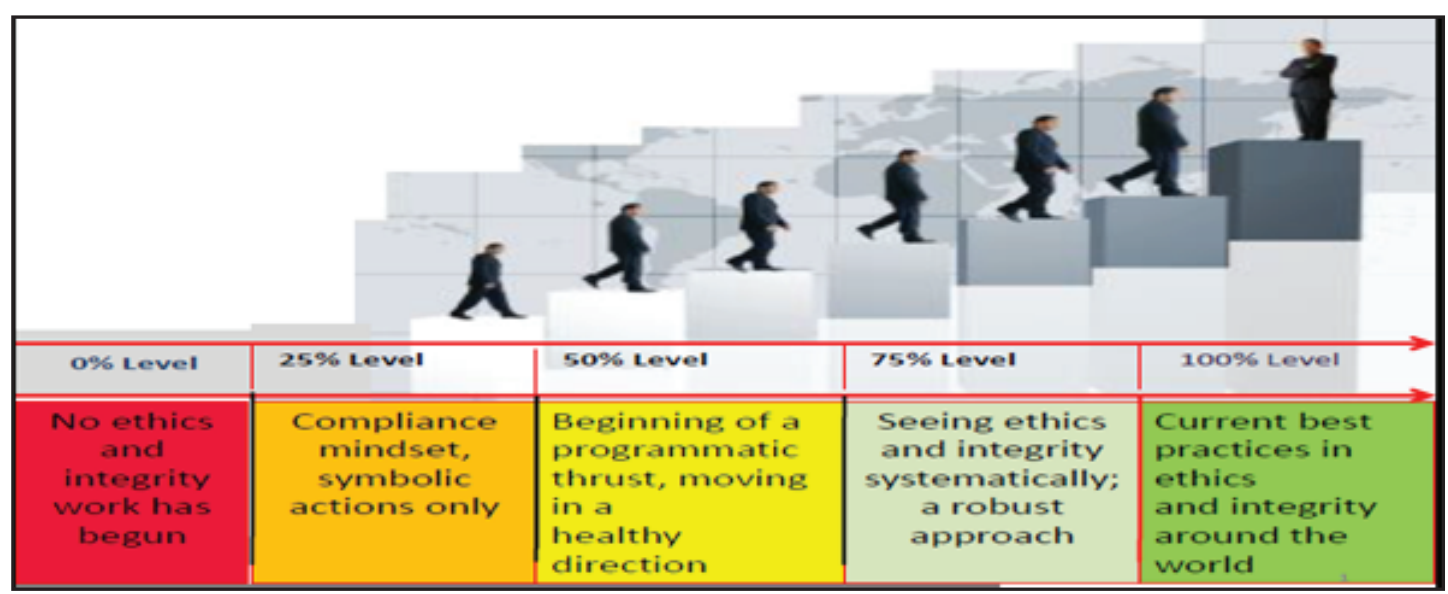

Figure 3: Five Ethics and Integrity Benchmarks Level of CISM (Source: Malaysian Institute of Integrity (IIM)).

\section{Results}

A total of 128 online questionnaires (Google form) were emailed to the Chief Integrity Officer (CIO) and the officers of Integrity Unit (IU) in the Malaysian public sector organization at the federal territory. Details of respondents such as name, contact number, address, position, and email address were obtained from the Agency Integrity Management Division (BPIA) of Malaysian Anti Corporation Commission (MACC) on August 2017. Data were collected within three months period starting from the second week of August 2017 until the end of October 2017. Eighty-three (83) officers responded to the survey; which made up $65 \%$ rate of response. Summary of the response rate is illustrated in Table 5. Profile of respondents is discussed in the next section.

TABLE 4: Summary of Response Rates.

Details

Questionnaires mailed

Questionnaire answered

Rate of Response (83/128) *100
Total

128

83

$65 \%$ 
Table 6 indicates the personal detail of the respondent such as gender, race, religion, and the level of education. The results showed that more than half whereby, 53 respondents $(63.9 \%)$ were male, while the remaining 30 respondents $(36.1 \%)$ were female. The respondents were represented by four racial compositions that were Malay (91.6\%), Chinese (2.4\%), Indians (3.6\%), and others (2.4\% including Siamese and Orang Asli). Most of the respondents were Muslims (95'2\%), followed by Buddhism (2.4\%) and Christians (1.2\%). Most of the respondents (43.3\%) were in the age range of 35 to 44 years old, followed by 45 to 55 years old (22.9\%), 25 to 34 years old (18.1\%) and the least 55 years old and above (15.7\%). Almost half of the respondents possess a bachelor's degree (49.4\%), followed by a master's degree (39.8\%), diploma (8.4\%) and others (2.4\%).

For the working place type of organization consists of seven departments namely Jabatan Kemajuan Orang Asli, Jabatan Hal Ehwal Khas (Unit Integriti), Jabatan Perangkaan Malaysia, Jabatan Bantuan Guaman, Jabatan Wakaf Dan Haji, Jabatan Pertanian Semenanjung Malaysia, and Jabatan Taman Laut Malaysia. The existence of the integrity unit for any breach of ethics and integrity in the past five years, whether the respondent is the head of the integrity unit or not. The next category inquires more details on the respondent's related matter with the integrity unit which include the full designation of respondents, either they obtain any professional certificate or qualification related to ethics and integrity program. Their working experience related to ethics and integrity portfolio, the operational and functional reporting level as well as the existence of other officers' responsibility for managing the ethics and integrity programme independently are important.

In the descriptive statistics of the principal construct, the mean was applied as a measure of central tendency, which showed that all variables were above their midpoint level (Sekaran, 2003). Table 7 shows a summary of descriptive statistics for all independent variables. The highest mean of 4.21 is recorded by work performance (one of the Qualities of chief integrity officer dimensions) with standard deviation (SD) of 0.79 , followed by ethical climate (mean value 4.10 , SD 0.32 ). This indicates that the respondents strongly agree with all items regarding the work performance and ethical climate in the organisation.

Table 8 shows the descriptive statistics for dependent variable such as level of ethics and integrity which comprises of twelve dimensions. Overall, it shows that the mean score of the twelve components range from 3.30 to 4.20 , indicating that respondents rated the items in each dimension as above average or at least scale 3 (neutral). 
TABLE 5: Summary of Profile Respondents.

\begin{tabular}{|c|c|c|c|}
\hline Demographic & Characteristic & Frequency (N:83) & Percentage (\%) \\
\hline \multirow[t]{2}{*}{ Gender } & Male & 53 & 63.9 \\
\hline & Female & 30 & 36.1 \\
\hline \multirow[t]{4}{*}{ Race } & Malay & 76 & 91.6 \\
\hline & Chinese & 2 & 2.4 \\
\hline & Indian & 3 & 3.6 \\
\hline & Others & 2 & 2.4 \\
\hline \multirow[t]{4}{*}{ Religion } & Muslim & 79 & 95.2 \\
\hline & Buddhism & 1 & 1.2 \\
\hline & Christianity & 1 & 1.2 \\
\hline & Others & 2 & 2.4 \\
\hline \multirow[t]{4}{*}{ Age } & 25-34 Years & 15 & 18.1 \\
\hline & 35-44 Years & 36 & 43.3 \\
\hline & 45-54 Years & 19 & 22.9 \\
\hline & 55 and above & 13 & 15.7 \\
\hline \multirow[t]{4}{*}{ Highest Qualification } & Master & 33 & 39.8 \\
\hline & Degree & 41 & 49.4 \\
\hline & Diploma & 7 & 8.4 \\
\hline & Others & 2 & 2.4 \\
\hline \multirow{3}{*}{$\begin{array}{l}\text { Working Place: Type of } \\
\text { Organization }\end{array}$} & Ministries & 63 & 75.9 \\
\hline & Department & 7 & 8.43 \\
\hline & Statutory Body & 13 & 15.7 \\
\hline
\end{tabular}

TABLE 6: Summary of Descriptive Statistics for Independent Variables.

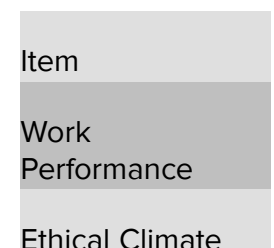

Ethical Climate
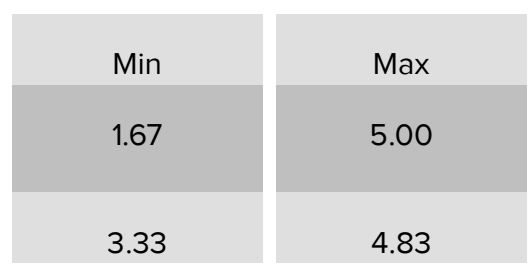
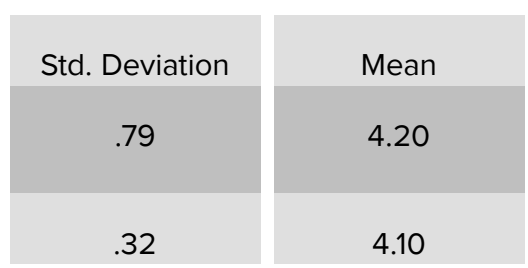

Meanwhile, the standard deviation of the twelve dimensions ranges from 0.37 to 0.75 , which shows not much of a variation between the respondents' answer. Out of the twelve components, infrastructure showed the lowest score with a mean of 3.30 and standard deviation of 0.37 , indicating that the respondents view the way organization 
organizes ethics and integrity on function structure, staff, resources, formal or informal reporting as average. The dimension of legal compliance, policies, and rules scored the highest mean of 4.20 with a standard deviation of 0.56 , indicating that the respondents agree the organizations that adopted laws, policies, rules, and guidance, ethics, and integrity system with the best practices in the organization.

TABLE 7: Summary of Descriptive Statistics for 12 Dimensions of Ethics and Integrity.

\begin{tabular}{|c|c|c|c|c|c|}
\hline Item & Items & Min & Max & $\begin{array}{c}\text { Std. } \\
\text { Deviation }\end{array}$ & Mean \\
\hline $\begin{array}{l}\text { Legal Compliance, Policies and } \\
\text { Rules }\end{array}$ & 14 & 3.00 & 5.00 & .56 & 4.20 \\
\hline Disciplinary Measure and Rewards & 11 & 2.55 & 5.00 & .63 & 4.11 \\
\hline Vision and Goals & 12 & 3.00 & 4.75 & .47 & 4.08 \\
\hline Leadership & 14 & 1.93 & 5.00 & .68 & 4.07 \\
\hline Accountability & 5 & 3.00 & 5.00 & .64 & 4.05 \\
\hline Whistleblowing & 9 & 2.78 & 5.00 & .67 & 4.04 \\
\hline Organizational Structure & 12 & 2.58 & 5.00 & .61 & 4.04 \\
\hline Ethics Communications & 14 & 2.21 & 5.00 & .72 & 4.04 \\
\hline Confidential Advices and Support & 8 & 2.75 & 5.00 & .68 & 3.92 \\
\hline Ethics Training and Education & 9 & 1.33 & 5.00 & .75 & 3.87 \\
\hline $\begin{array}{l}\text { Measurements, Research and } \\
\text { Assessment }\end{array}$ & 11 & 2.09 & 5.00 & .70 & 3.86 \\
\hline Infrastructure & 5 & 2.40 & 4.20 & .37 & 3.30 \\
\hline
\end{tabular}

Table 9 illustrates each of the independent variables included in the model contributed deeper to the prediction of the dependent variable. This was done by analysing the Coefficients output for hypotheses study. The largest beta coefficient is 0.32 was scored by work performance (WP). This means that this variable makes the strongest unique contribution in explaining the level of ethics and integrity, whereby the variance explained by all other variables in the model is controlled. The Beta value for ethical climate $(E C)$ was slightly lower 0.27 , indicating that it made less of a unique contribution. 
TABLE 8: Summary of Hypotheses Testing of Coefficients (Relationship between Independence, Competence, Work Performance and Ethical Climate with the Level of Ethics and Integrity).

\begin{tabular}{|c|c|c|c|c|c|c|c|c|c|}
\hline \multirow[t]{2}{*}{ Hypo } & \multirow[t]{2}{*}{$\begin{array}{l}\text { Independent } \\
\text { Variables }\end{array}$} & \multicolumn{2}{|c|}{$\begin{array}{l}\text { Unstandardized } \\
\text { Coefficients }\end{array}$} & \multirow{2}{*}{$\begin{array}{c}\text { Standardized } \\
\text { Coefficient } \\
\text { Beta }\end{array}$} & \multirow{2}{*}{ t-value } & \multirow[t]{2}{*}{ Sig. } & \multicolumn{2}{|c|}{ Collinearity Statistics } & \multirow[t]{2}{*}{ Decision } \\
\hline & & Beta & $\begin{array}{l}\text { Std. } \\
\text { Error }\end{array}$ & & & & Tolerance & VIF & \\
\hline & (Constant) & .973 & & & 1.486 & .141 & & 5.089 & \\
\hline H1a & Independence & .233 & .655 & .095 & .941 & .050 & -0.43 & 1.444 & $\begin{array}{c}\text { Not } \\
\text { Significant }\end{array}$ \\
\hline $\mathrm{H} 1 \mathrm{~b}$ & Competence & .456 & .248 & .162 & 1.684 & $.096 * *$ & -0.65 & 2.291 & Significant \\
\hline $\mathrm{H} 1 \mathrm{c}$ & Work Perform & .204 & .066 & .315 & 3.093 & $.003^{*}$ & 0.01 & 0.711 & Significant \\
\hline $\mathrm{H} 2$ & Ethical Climate & .426 & .167 & .270 & 2.577 & $.012^{*}$ & 0.15 & 1.550 & Significant \\
\hline
\end{tabular}

\section{Discussion}

Independence was found not to have a significant relationship with the level of ethics and integrity. This result is consistent with Qun (2013), where he found that independence was not significant in determining internal audit effectiveness. In this study, independence was also found not significant in determining the level of ethics and integrity. This implies that the reporting level used as the proxy of the independence dimension does not affect the quality of Chief Integrity Officer. In addition to that, it was found that both operational and functional reporting level in this current study was to their head of department. One of the possible reasons is because, unlike previous studies, this study focused on the public sector entities where the culture of reporting is directly referred to the immediate superior for any issues that raised.

The second dimension of the quality of chief integrity officer $(\mathrm{CIO})$ was competence. It was found to have a significant and positive relationship with the level of ethics and integrity in the Malaysian public sector organizations studied in this research. Competence in this study refers to the working experience and the level of education. The finding in this study is in line with the previous research by Irwin and Bradshaw (2011). They also found that the more competence officer will influence good ethics programs to be in place. Hunt and Vintel (1986,) had also discussed the significance of competence in some ethical judgment models explained in their Theory of Ethics. Indirectly, previous research conducted by Mihret and Yismaw (2007), Rai (2008) and 
Qun (2013) had found that the competency of the personnel is a critical factor in determining the overall quality of their expert field. These researchers agreed upon the finding on which competence internal auditors are required to ensure they performed their audit works properly and at the highest quality. Similarly, if the officers in this current study possess the competency such as work experience related to ethics and integrity, the skills and knowledge regarding the ethics and integrity, it is most likely that they will contribute to the overall quality of Chief Integrity Officer which subsequently influence the level of ethics and integrity in the organization. For instance, the competency level of $\mathrm{CIO}$ in this study is quite high where almost $90 \%$ of the respondents have either master's degree or a bachelor's degree qualification with $42 \%$ of the respondents have an average year of services related to ethics and integrity for more than 12 years. Moreover, more than $80 \%$ of respondents own a professional certificate or qualification related to ethics and integrity program. These had contributed to the high percentage score level of ethics and integrity obtained in this study. Hence, it can be concluded that the concern of engaging the right person with suitable skills especially the Chief Integrity Officer would be portrayed through the improvement on the level of ethics and integrity in their respective organizations. This can also be supported by recent quotes in the local online newspaper stating that the certified integrity officers during their five-year service, had taken down 4,000 complaints and pursued to the end 1,600 of the complaints including those classified as "misconduct" (News Strait Times, 2018).

The dimension of Quality of $\mathrm{ClO}$, work performance has the highest mean score of 4.21 , indicating that respondents mostly agreed with the job description of the chief integrity officer. Work performance also scored the largest beta coefficients (0.32) in the multiple regression analysis indicating that this dimension has the strongest contribution in explaining the variance of the level of ethics and integrity. This finding is in line with the research paper published by Treviño et al. (2014) where they found that the efforts of ethics and compliance officer to initiate and manage a variety of ethics and integrityrelated programs can be beneficial in terms of improving employees' perceptions and decreasing inappropriate conduct. The work performance as the dimension of the personnel's quality is also supported by the previous research conducted by Qun (2013). He found that the work performance of the internal auditors contributes to the overall quality of internal auditors. Respondents perceived that they are responsible to coordinate and monitor the ethics and integrity programme as well as implementing a recovery integrity program, monitoring the services delivery system in the organization, and assisting the Integrity and Governance Committee. Moreover, they are also in 
charge of coordinating the actions taken on the breach of ethics and integrity. Integrating all these work scope responsibilities, it ensures the quality of chief integrity officer and eventually contributes in the higher percentage score level of ethics and integrity as discussed in the previous section.

Ethical climate was found to have significant and positive relationship with the level of ethics and integrity (Beta coefficient 0.27; $p<0.05$; confidence interval 95\%). This is supported by the Hunt and Vitell's Theory of Ethics (1986,) where apart from personal characteristics which are the quality of $\mathrm{ClO}$, the organizational environment also plays crucial factors in influencing the level of ethics and integrity in the organization. In this study, this organizational environment is represented by the ethical climate. In other words, the ethical climate of the organization may influence the ethical decision and attitude or behaviour making, which eventually gives impact to the level of ethics and integrity. This finding is also consistent with research conducted by Chouaib and Zaddem (2013) which suggested that the ethical climate have an impact on the effectiveness trust of work and consequently, increase the level of ethics and integrity within the organization. The ethical climate was also found to be a critical factor in influencing the employees' perception of how their organization emphasizes the ethical aspect of business and encourages employees ethical work behaviours (Kwon et al., 2013). Similarly, Shafer (2015) analysed the ethical climate of professional accountants in Hong Kong and reported that there is a significant relationship with ethical judgment on an organization. The mean score obtained for this variable is also quite high which is 4.09. The high mean value indicates that the respondents perceived their organization practices a high ethical climate in the public sector. This study also found that the public sector organizations promote a transparent ethical surrounding, implements a strict code of ethical rules and enforces mechanism to prevent unethical behaviour. These are essential factors in creating an awareness of ethical and integrity among public servants.

\section{Contribution}

Thus, the contributions made by this study is useful for raising awareness, especially among the public employee to adopt good governance in various ways to ensure the organization is more influenced by an ethics and integrity environment in the public sector. Thus, an office of integrity should be set up with full authority to implement ethical activities. The organizations in the ministry department and statutory body can be 
headed by a Chief Integrity Officer with sufficient funding given to carry out their duties and promote and disseminate on ethics and integrity. And, through competence which is through experience and education level and work performance which is the job scope of quality of $\mathrm{ClO}$ become significant to increase the level of ethics and integrity in the public sector. $\mathrm{ClO}$ with these attributes will contribute insights and can help to improve the integrity unit in the organizations so that the level of ethics and integrity can be increased higher and consequently, reduce the unethical scandals in the organization. The competence level of the $\mathrm{ClO}$ is measured based on their experience and level of education. With regards to that, by appointing a highly experienced and skilled $\mathrm{ClO}$, it could help in solving the unethical scandal effectively. To increase the competency level of the $\mathrm{ClO}$, they are highly advised to enroll in more professional qualification courses related to ethics and integrity. All $\mathrm{ClO}$ should have graduated with the Certified Integrity Officer course provided by the Malaysian Anti-Commission Academy (MACA). The government can also improve the existing ethical climate by implementing the control and monitoring procedure of the employee at various departments of the public sector to enhance the ethical behavioural practices. This is Iso that, employees at the public sector are expected to perform high integrity and high ethical values consistently during the undertaking of their tasks with transparency and responsibility. Other than that, top management should look at the procedure, code of conduct, legislation, and guideline as these plays a major role in influencing the level of ethics and integrity in public sector organisations. Despite many efforts taken to increase the level of integrity, the number of complaints and the number of arrested people remains high. To create the culture and climate of integrity, the civil servants are encouraged to participate in seminars on integrity, forums, and dialogues organized by relevant agencies and organizations. Besides that, these initiatives are concurrently strengthened with compliance constructs such as the national pillars (Rukun Negara), code of ethics, integrity pledge, general circulars and many other formal documents expounding good values.

\section{Limitations and Suggestion for Future Research}

The limitations and suggestion of this study for future research on a similar topic to make an improvement in this study field. Firstly, the number of samples should be increased and could be focused on the Chief Integrity Officers who have graduated the Certified Integrity Officer course conducted by Malaysian Anti-Corruption Academy, in other words, the future study focuses on CelO (Chief Integrity Officers). Therefore, 
the effectiveness of those in charge of integrity, who has gone through the certification process can be examined. Furthermore, the sample studied can be extended to include the ethics officers from the State Government and a comparison can be made between the ethics officers at the Federal Government. Future research may also include an analysis of gender and the focuses on the integrity unit in public sector organizations all over Malaysia for both states departments and government link agencies along with the federal departments. Interviews can also be done to enable a more in-depth explanation of issues studied. Moreover, on the issue of the distribution of the questionnaire, the researcher should deliver it personally to the respondents personally, so that the researcher may take the opportunity to conduct a briefing session on explaining the questionnaire to the respondent rather than using online questionnaire. By doing so, this could avoid any potential conflict or misunderstanding among the respondents. In addition to that, the number of questionnaires for the respondent needs to be reduced and analyzed by using PLS-SEM. It is strongly suggested that the research approach could possibly be utilized by a qualitative research approach such as an in-depth interview with the Chief Integrity Officers with case studies approaches in combination with survey questionnaires.

\section{Acknowledgement}

A special thanks is dedicated to all research group members, Institute of Integrity Auditor Malaysia (IIM), Mrs. Rasidah Binti Abdul Karim who is the Head of Corporate Integrity Development Centre in the Malaysian Anti-Corruption Academy (MACA), Mr Alan Kirupakaran who is the Governance Officer of Minister in the Prime Minister's Department, Institute of Internal Auditor Malaysia (IIAM), National Audit Department (NAD) of Malaysia and associate members of FIM's Governance and Integrity Centre (FGIC). The usual disclaimer applies.

We would like to thank Yayasan Bank Rakyat for the financial support by sponsoring this paper to be presented in the FGIC $2^{\text {nd }}$ Conference on Governance and Integrity 2019.

\section{Appendix 1}




\section{Descriptive of CISM 12 Categories Items for Level of Ethics and Integrity}

\begin{tabular}{|c|c|c|}
\hline Dimension & Items & Description \\
\hline Vision and Goals & Q1-Q19 & $\begin{array}{l}\text { This section covers the organization's overall concept of and } \\
\text { approach to ethics and integrity, including its formal articulation } \\
\text { of the organization's underlying philosophy about ethical and } \\
\text { moral conduct, and how these expectations are embedded in } \\
\text { the fabric of the organization. This benchmark includes how } \\
\text { organizations identify and define their core ethical values or } \\
\text { principles, as well as how organizations integrate those values } \\
\text { into everyday business conduct. }\end{array}$ \\
\hline Leadership & Q1-Q21 & $\begin{array}{l}\text { This section covers the responsibilities of the organization's } \\
\text { leadership in shaping, guiding, and supporting the } \\
\text { organization's ethics and integrity initiatives. It examines how } \\
\text { leaders and managers are held accountable for promoting } \\
\text { ethics and integrity. This category includes an assessment of the } \\
\text { organization's "Tone from the Top" at both the senior executive } \\
\text { and governance levels. }\end{array}$ \\
\hline Infrastructure & Q1-Q17 & $\begin{array}{l}\text { This section explores the way the organization structures or } \\
\text { organizes its ethics and integrity function so that it can carry out } \\
\text { its goals effectively. This category covers how the ethics } \\
\text { function is structured, staffed, and resourced, as well as its } \\
\text { formal and informal reporting relationships. This category also } \\
\text { includes the roles and responsibilities of those individuals who } \\
\text { are assigned to implement the ethics and integrity function. }\end{array}$ \\
\hline $\begin{array}{l}\text { Legal Compliance, } \\
\text { Policies and Rules }\end{array}$ & Q1-Q17 & $\begin{array}{l}\text { This section includes core laws, policies, rules, and guidance } \\
\text { that comprise the legal framework for the organization's ethics } \\
\text { and integrity systems. This section assesses the internal } \\
\text { framework that provides the floor for ethical behaviour. It also } \\
\text { includes compliance with the external legal frameworks within } \\
\text { which the organization operates. This section includes the } \\
\text { systems and controls used to ensure and demonstrate that } \\
\text { employees and the organization are legally compliant. } \\
\text { Essentially, the organization has translated its legal commitments } \\
\text { into concrete actionable guidance that is enforceable. }\end{array}$ \\
\hline $\begin{array}{l}\text { Organizational } \\
\text { Culture }\end{array}$ & Q1-Q20 & $\begin{array}{l}\text { This section deals with the overall organization culture and how } \\
\text { it promotes ethical conduct in the context of the organizational } \\
\text { mission, vision, structure, and strategy. This section explores the } \\
\text { degree to which an organization focuses on shaping its } \\
\text { organizational culture (both written and unwritten rules that } \\
\text { dictate how work is performed and goals reached) and whether } \\
\text { that culture actively promotes ethical conduct. This section } \\
\text { addresses how culture is defined (the history and traditions of } \\
\text { the organization), who "owns" and shapes culture, how culture is } \\
\text { measured, and the degree to which employees find the culture } \\
\text { supportive of ethics and integrity. }\end{array}$ \\
\hline $\begin{array}{l}\text { Disciplinary and } \\
\text { Reward Measures }\end{array}$ & Q1-Q17 & $\begin{array}{l}\text { This section attempts to examine how the organization sets and } \\
\text { enforces its standards for ethical conduct and behaving with } \\
\text { integrity. This section also addresses rewards and punishments, } \\
\text { incentives that promote ethical behaviour, and disciplinary } \\
\text { action taken to limit or punish unethical work conduct. This } \\
\text { section includes how the organization promotes ethical conduct } \\
\text { through its performance appraisal process, and whether ethical } \\
\text { conduct is linked to compensation and/or other types of } \\
\text { non-monetary benefits. }\end{array}$ \\
\hline
\end{tabular}




\begin{tabular}{|c|c|c|}
\hline Dimension & Items & Description \\
\hline $\begin{array}{l}\text { Measurement, } \\
\text { Research and } \\
\text { Assessment }\end{array}$ & Q1-Q17 & $\begin{array}{l}\text { This section evaluates how ethics and integrity are measured, } \\
\text { whether your organization undertakes research to support } \\
\text { ethics strategies that create a culture of ethics and integrity, and } \\
\text { the organization's assessment processes around ethics, integrity } \\
\text { and organizational culture. This category includes the } \\
\text { organization's commitment to continuous improvement, based } \\
\text { on benchmarking and other evaluation methodologies. }\end{array}$ \\
\hline $\begin{array}{l}\text { Confidential } \\
\text { Advice and } \\
\text { Support }\end{array}$ & Q1-Q16 & $\begin{array}{l}\text { This section covers describes how the organization provides } \\
\text { confidential, neutral, professional and independent ethics } \\
\text { advice to employees, supervisors, managers, executives, } \\
\text { members of the governing bodies and other stakeholders. }\end{array}$ \\
\hline $\begin{array}{l}\text { Ethics, Training } \\
\text { and Education }\end{array}$ & Q1-Q18 & $\begin{array}{l}\text { This section explores ethics and integrity awareness, } \\
\text { skill-building training and education, and the integration of such } \\
\text { training into the overall development of all employees. This } \\
\text { category includes the provision of ethics-related training and } \\
\text { skill building throughout the life cycle of staff members, and the } \\
\text { degree to which these initiatives are integrated into other } \\
\text { organization-wide training commitments. }\end{array}$ \\
\hline $\begin{array}{l}\text { Ethics } \\
\text { Communication }\end{array}$ & Q1-Q18 & $\begin{array}{l}\text { This section describes how the ethics and integrity initiative is } \\
\text { articulated and promoted, both internally and externally. This } \\
\text { category covers how the organization defines its stakeholders } \\
\text { and how it gears its key messages to distinct audiences. }\end{array}$ \\
\hline Whistleblowing & Q1-Q18 & $\begin{array}{l}\text { This section explores how organization encourages individuals } \\
\text { (both internal and external to the entity) to speak up and make } \\
\text { reports of questionable conduct. This category explores the } \\
\text { methods and protections offered to individuals who wish to } \\
\text { make the organization aware of possible unethical behaviour, } \\
\text { misconduct or any illegal actions. It includes the making of both } \\
\text { confidential and anonymous reports, and the systems used by } \\
\text { the organization to protect whistle-blowers from retaliation or } \\
\text { retribution. }\end{array}$ \\
\hline Accountability & Q1-Q10 & $\begin{array}{l}\text { Respondents are required to indicate the level of agreement to } \\
\text { each statement. }\end{array}$ \\
\hline
\end{tabular}

\section{References}

[1] Accounting Research Institute (2016). Corruption Risk and Mitigation Approaches in Public and Private Sector. Retrieved on 26 August from http://ari.uitm.edu.my/main/ index.php/hicoe-research-cluster/corporate-integrity-ethics-and-risk-management

[2] Abbott, L.J., Parker, S. and Peters, G. (2004), "Audit committee characteristics and restatements", Auditing: A Journal of Practice \& Theory, Vol. 23 No. 1, pp. 69-87.

[3] Ali, E. I. E. (2015). Public sector accounting and financial management in Malaysia. Malaysia: Unpublished First Draf

[4] Aliza Shah (2018, July 16). [Exclusive] 28 Integrity Officers to be reinstated. New Strait Times. Retrieved: from://https://www.nst.com.my/news/exclusive/2018/ 07/391197/exclusive-28-integrity-officers-be-reinstated

[5] Baker, J., Mapes, J., New, C. \& Szwejczewski, M. 1997. A hierarchical model of business competence. Integrated Manufacturing Systems Vol. 8 No. 5/1997, 265- 
272

[6] Bartels, L.K., Harrick, E., Martell, K. and Strickland, D. (1998), "The relationship between ethical climate and ethical problems within human resource management", Journal of Business Ethics, Vol. 17 No. 7, pp. 799-804

[7] Blue Ribbon Committee (1999), "Report and recommendations of the Blue Ribbon Committee on improving the effectiveness of corporate audit committees", The Business Lawyer, Vol. 54 No. 3, pp. 1067-1095

[8] Buller, P.F. and McEvoy, G.M. (1999), "Creating and sustaining ethical capability in the multi-national corporation", Journal of World Business, Vol. 34 No. 4, pp. 326-343

[9] Camerer, M.I. (2006). Measuring public integrity. Journal of Democracy, 17 (1), 152-165

[10] Chandler, D. (2015). Institutions and Ideals: Philip Selznick's Legacy for Organizational Studies. Research in the Sociology of Organizations, 44, 149-174. https://doi.org/10. $1108 /$ S0733-558X201544

[11] Circular No.1 Year (2009) and Series 1 No. 1Year (2011) - Directive YAB Prime Minister: Gerakan Pemantapan Keutuhan Sistem Pengurusan Pentadbiran Kerajaan Malaysia, Pelaksanaan Program Pegawai Integriti Bertauliah

[12] Corporate Intgrity System Malaysia (CISM) Official Website. The Journey. Retrieved from http://www.cism.my/aboutcism/journey, 2016

[13] Corruption Perception Index, Transparency International (TI) (2017). Retrieved on 13 February, http;//www,transparency.org/news/feature/ corruption_perception_index_2016,

[14] Cyert, R. and March, J. (1963). The Behavioural Theory of the Firm. Englewood Cliffs, NJ: Prentice Hall

[15] Dacin, M. T., Munir, K., \& Tracey, P. (2010). Formal dining at Cambridge colleges: Linking ritual performance and institutional maintenance. Academy of Management Journal, 53(6), 13931418.

[16] Dubinsky, J. E., \& Richter, A. (2008). Global Ethics and Integrity Benchmark. US

[17] Dubsinky, J. E., \& Richter, A. (2009). Global Ethics and Integrity Benchmark US

[18] Erpenbeck, J. and Michel, L.P. (2006), "Competency-based quality securing of elearning (CQ-E)", in Ehlers, U.-D. and Pawlowski, J.M. (Eds), Handbook on Quality and Standardisation in E-Learning, Springer, Berlin and Heidelberg, pp. 125-141.

[19] Frey, A. and Ruppert, J.-J. (2013), "Structuring and detecting competence", in Beck, K. and Zlatkin-Troitschanskaia, O. (Eds), From Diagnostics to Learning Success, Sense, Rotterdam, pp. 185-198 
[20] Governance Integrity Anti-Corruption Centre (GIACC). (2019). National AntiCorruption Plan (NACP) 2019 - 2023. Retrieved from http://integriti.my/giacc/wpcontent/uploads/2019/01/National-Anti-Corruption-Plan-2019-2023.pdf

[21] Ghazali, N.A.M., \& Ismail, S. (2013). The influence of personal attributes and organizational ethics position on accountants' judgment: Malaysian scenario. Social Responsibility Journal, 9(2), 281-297

[22] Haron, H., Ismail, I., \& Na, A. Lo. (2015). The Effect of Moral Reasoning, Exposure to Ethics and Perceived Ethical Climate on Ethical Judgement of Auditors in Malaysia, $8(2), 25-66$

[23] Heinen, T. (2011), Planung der soziotechnischen Wandlungsfähigkeit in Fabriken, PZH, Garbsen

[24] Hunt, S.D., \& Vitell, S.J., (1993). A General Theory of Marketing Ethics: A Retrospective and Revision. In Ethics in Marketing ,pp.775-784, (N.C. Smith \& J.A.Quelch (Ed)

[25] Hunt, S.D., \& Vitell, S.J. (1986). A general theory of marketing ethics. Journal of Macromarketing, 6(1), 5-16

[26] Hunt, S.D., Wood, V.R. and Chonko, L.B. (1989), "Corporate ethical values and organizational commitment in marketing", Journal of Marketing, Vol. 53 No. 3, pp. 79-90.

[27] Hunt, S.D., \& Vitell, S.J., (1993). A General Theory of Marketing Ethics: A Retrospective and Revision. In Ethics in Marketing,pp.775-784, (N.C. Smith \& J.A.Quelch (Ed)

[28] Institute of Internal Auditors (IIAM). (2008), The International Professional Practices Framework

[29] Irwin, J., \& Bradshaw, K. (2011). The ethics challenge: establish an ethics ambassador network to help embed an ethical culture. Strategic HR Review, 10(4), 26-32. Retrieved://doi. org /10.1108/14754391111140972

[30] Jaramillo, F., Mulki, J.P. and Solomon, P. (2006), "The role of ethical climate on salesperson's role stress, job attitudes, turnover intention, and job performance", Journal of Personal Selling \& Sales Management, Vol. 26 No. 3, pp. 271-282.

[31] Kamaliah, Marjuni, Mohamed, Mohd-Sanusi \& Anugerah, 2018 (Effectiveness of monitoring mechanisms and mitigstions of fraud incidents in the public sector, 2018

[32] Kauffeld, S. (2006), "Self-directed work groups and team competence", Journal of Occupational and Organizational Psychology, Vol. 79 No. 1, pp. 1-21

[33] Kolthoff, E., Erakovich, R., \& Lasthuizen, K. (2010). Comparative analysis of ethical leadership and ethical culture in local government: The USA, The Netherlands, Montenegro and Serbia. International Journal of Public Sector Management, 23(7), 596-612. https://doi.org/10.1108/09513551011078879 
[34] Koopmans, L., Bernaards, C. M., Hildebrandt, V. H., Schaufeli, W. B., de Vet Henrica, C. W., \& van der Beek, A. J. (2011). Conceptual Frameworks of Individual Work Performance. Journal of Occupational and Environmental Medicine, 53(8), 856866. https://doi.org/10.1097/JOM.0b013e318226a763

[35] Kwon Choi, B., Koo Moon, H., \& Ko, W. (2013). An organization's ethical climate, innovation, and performance. Management Decision, 51(6), 1250-1275. https://doi. org/10.1108/MD-Sep-2011-0334

[36] Laratta, R. (2008). Ethical Climate in Nonprofit and Government Sectors: A Comparative Study between Japan and UK. Young, (2004), 1-14. https://doi.org/ 10.1080/14719037.2010.501620

[37] Lok, J., \& de Rond, M. (2013). On the plasticity of institutions: Containing and restoring practice breakdowns at the Cambridge University boat club. Academy of Management Journal, 56(1), 185207

[38] Lokman. A \& Talib T. A, (2015). The Public of Administrators. Conference: The 5th International Conference on Public Policy \& Social Science, At Seremban Malaysia

[39] Malaymail (2017, March 01). Public Sector Governance: Filling The Gap - Latifah Merican Cheong. Malaymail. Retrieved from https://www.malaymail.com/

[40] Martin, K.D. and Cullen, J.B. (2006), "Continuities and extensions of ethical climate theory: a meta-analytic review", Journal of Business Ethics, Vol. 69 No. 2, pp. 175-194

[41] Marta, J.K.M. (1999), "An empirical investigation into significant factors of moral reasoning and their influences on ethical judgment and intentions", doctoral dissertation, Old Dominion University, Norfolk, VA (UMI No: 9928703), available at: www.proquest.umi.com.html (accessed May 24, 2006).

[42] Meyer, G., Brünig, B., \& Nyhuis, P. (2015). Employee competences in manufacturing companies - an expert survey. 34(8), 1004-1018. https://doi.org/10.1108/JMD-062014-0056

[43] Mujeeb Ehtesham, Tahir Masood Muhammad, Shakil Ahmad Muhammad. 2011. Relationship between Organizational Culture and Performance Management Practices: A Case of University in Pakistan. Journal of Competitiveness. Issue 4/2011, pp. 78-86

[44] Nabila, A. A. (2008). The relationship between Psychological Empowerment and organizational Commitment: A case study among employees in construction sector in Kota Kinabalu, Sabah. School of Business and Economic, UMS

[45] NKRA E-Newletter (2013). Certified Integrity Officer Programme (CelO) Enculturing integrity and ethics at the work place. 
[46] Patterson, D.M. (1994), "A model of ethical/unethical decision making by auditors in the big-six accounting firms", doctoral dissertation, Georgia State University, Atlanta, GA, available at: www.proquest.umi.com (accessed April 21, 2005)

[47] Persons, O. S. (2005) The relation between the new corporate governance rules and the likelihood of financial statement fraud. Review of Accounting \& Finance, 4(2), 125-148

[48] Pimental, J. R. C., Kuntz, J.R.., \& Elenkov, D. S. (2010). Ethical decision-making an integrative model for business practices. European Business Review, 22 (4), 359 376.

[49] Qun, T. C. (2013). Internal audit quality, audit committee quality, symbiotic relationship between audit committee and internal audit effectiveness.

[50] Rauner, F., Heinemann, L., Maurer, A., Haasler, B., Erdwien, B. and Martens, T. (2013), "Measuring professional competence", in Rauner, F., Heinemann, L., Maurer, A. and Haasler, B. (Eds), Competence Development and Assessment in TVET (COMET), Springer Science + Business Media, Dordrecht, pp. 1-17.

[51] Said, J., Alam, M. M., \& Khalid, M. A. (2015). Relationship between good governance and integrity system: empirical study on the public sector of Malaysia. Humanomics, 32(2), 354-371. https://doi.org/10.1108/H-04-2014-0037

[52] Schminke, M., Arnaud, A. and Kuenzi, M. (2007), “The power of ethical work climates”, Organizational Dynamics, Vol. 36 No. 2, pp. 171-186

[53] Selma, Altindis. 2011. Job motivation and organizational commitment among the health professionals. African Journal of Business Management. Vol. 5(21), pp. 86018609 ,

[54] Sethela June and Rosli Mahmood. 2011. The Relationship between Role Ambiguity, Competency and PersonJob Fit With the Job Performance of Employees in the Service Sector SMEs in Malaysia. Journal Business Management Dynamics. Vol.1, No.2, August 2011, pp.79-98

[55] Shafer, W.E. (2008). Ethical climate in Chinese CPA firms. Accounting, Organizations and Society, 33(7-8), 825-835.

[56] Shafer, W.E. (2015). Ethical climate, social responsibility, and earnings management. Journal of Business Ethics. 126(1), 43-60.

[57] Siddiquee, N. A. (2010). Combating corruption and managing integrity in Malaysia: A critical overview of recent strategies and initiatives. Public Organization Review, 10(2), 153-171. https://doi.org/10.1007/s11115-009-0102-y

[58] Sims, R.R. (1992), "The challenge of ethical behavior in organizations", Journal of Business Ethics, Vol. 11 pp.505-13 
[59] Torres, M.B., 2001. Character and Decision-Making. Doctoral dissertation, University of Navarra, Canada. Retreived April, 10, 2015 from http://www.proquest.umi.com

[60] Treviño, L. K., den Nieuwenboer, N. A., Kreiner, G. E., \& Bishop, D. G. (2014). Legitimating the legitimate: A grounded theory study of legitimacy work among Ethics and Compliance Officers. Organizational Behavior and Human Decision Processes, 123(2), 186-205. Retrived from: https://doi.org/10.1016/j.obhdp.2013.10. 009

[61] Ulrich, Dave, R. 1998. Intellectual Capital = Competence $\times$ Commitment. Sloan Management Review. Vol. 39 p. 15-26.

[62] Viswesvaran, C., \& Ones, D. S. (2000). Perspectives on models of job performance. International Journal of Selection and Assessment, 8(4), 216-226.

[63] Weaver, G. R., Treviño, L. K., \& Cochran, P. L. (1999a). Corporate ethics programs as control systems: Influences of executive commitment and environmental factors. Academy of Management Journal, 42(1), 4157. Weaver, G. R., Treviño, L. K., \& Cochran, P. L

[64] Zahariah Mohd Zain, Razanita Ishak, Erlane K Ghani. 2009. The Influence of Corporate Culture on Organizational Commitment. European Journal of Economics, Finance and Administrative Sciences. ISSN 1450-2275 Issue 17 pp. 16-26.

[65] Zakaria, M., Haron, H., \& Ismail, I, (2010). Knowledge of ethics, perceived ethical problem and ethical judgement. Journal of Financial Reporting and Accounting, 8 (1), 50-64, https://doi.org/10.1108/IJBM-07-2013-0069

[66] Chen, Z.-X., \& Tan, K. H. (2011). The perceived impact of JIT implementation on operations performance: Evidence from Chinese firms. Journal of Advances in Management Research, 8(2), 213-235. doi: 10.1108/09727981111175957

[67] Khanchanapong, T., Prajogo, D., Sohal, A. S., Cooper, B. K., Yeung, A. C. L., \& Cheng, T. C. E. (2014). The unique and complementary effects of manufacturing technologies and lean practices on manufacturing operational performance. International Journal of Production Economics, 153, 191-203. doi: 10.1016/j.jpe.2014.02.021

[68] Matsui, Y. (2007). An empirical analysis of just-in-time production in Japanese manufacturing companies. International Journal of Production Economics, 108(1-2), 153-164. doi: 10.1016/j.ijpe.2006.12.035

[69] Nawanir, G., Lim, K. T., \& Othman, S. N. (2013). Impact of lean practices on operations performance and business performance: some evidence from Indonesian manufacturing companies. Journal of Manufacturing Technology Management, 24(7), 1019-1050. doi: 10.1108/JMTM-03-2012-0027 
[70] Russell, R. S., \& Taylor, B. W. (2014). Operations management and supply chain management (8th ed.). Singapore: John Willey \& Sons, Inc.

[71] Taj, S., \& Morosan, C. (2011). The impact of lean operations on the Chinese manufacturing performance. Journal of Manufacturing Technology Management, 22(2), 223-240. doi: 10.1108/17410381111102234 